\title{
Inhibitor of the Factor Vlla-Tissue Factor Complex Is Reduced in Patients with Disseminated Intravascular Coagulation but Not in Patients with Severe Hepatocellular Disease
}

\author{
Madhu S. Bajaj, Satya V. Rana, Robert B. Wysolmerski, and S. Paul Bajaj \\ Section of Medicine, Biochemistry, and Pathology, St. Louis University School of Medicine, St. Louis, Missouri 63104
}

\begin{abstract}
Inhibition of Factor VIIa-tissue factor activity by a plasma component(s) that requires factor $\mathrm{Xa}$ has been described recently. In this communication, we have developed a specific radiometric assay (which utilizes ${ }^{3} \mathrm{H}$-Factor IX and is sensitive to $<1 \%$ of plasma level) for this inhibitor and have measured its activity in various disease states. Strikingly, the levels of this inhibitor were found to be normal in patients with advanced chronic hepatocellular disease but low in patients with disseminated intravascular coagulation (DIC). When endotoxin was used to induce DIC in rabbits, the levels of this inhibitor fell by 25-90\%. Human umbilical vein endothelial cells (HUVE), bovine pulmonary artery endothelial cells, and a human hepatoma cell line (HepG2) all synthesized and secreted this inhibitor, whereas a promyelocytic cell line (HL-60) did not and a monocytic cell line (U937) appears to synthesize only small amounts. When ammonium sulfate-fractionated human plasma and serum-free conditioned media from both HUVE and HepG2 cells were electrophoresed on sodium dodecyl sulfate acrylamide gels, two activity peaks corresponding to $M_{\mathrm{r}} \sim 45,000$ and $M_{\mathrm{r}} \sim 33,000$ were eluted in each case. These observations suggest that (a) the inhibitor is consumed in DIC and that (b) endothelial cells (or other cells) synthesize sufficient amounts of this inhibitor in vivo to compensate for any decreased production by liver cells.
\end{abstract}

\section{Introduction}

The tissue factor pathway of blood coagulation may play a primary role in hemostasis, because Factor VIIa-tissue factor (VIIa/ $\mathrm{TF})^{1}$ complex not only activates Factor $\mathrm{X}$ but also Factor IX, thus bypassing the contact activation reactions of the classical intrinsic pathway $(1,2)$. Furthermore, substantial evidence exists

Address correspondence to Dr. S. Paul Bajaj, Hematology Division, St. Louis University Medical Center, 1325 South Grand Boulevard, St. Louis, MO 63104.

Received for publication 21 January 1987.

1. Abbreviations used in this paper: VIIa/TF, complex of Factor VIIa and tissue factor; BPAE, bovine pulmonary artery endothelial cell; DEGR-CK, dansyl-glu-gly-arg-chloromethyl ketone; DIC, disseminated intravascular coagulation; HPP, human pooled plasma; HUVE, human umbilical vein endothelial cell; RPP, rabbit pooled plasma.

J. Clin. Invest.

(c) The American Society for Clinical Investigation, Inc.

$0021-9738 / 87 / 06 / 1874 / 05 \quad \$ 1.00$

Volume 79, June 1987, 1874-1878 that there is an inhibitor in plasma that turns off the coagulation initiated by the VIIa/TF complex (3-5). This inhibitor could be a physiologically important variable influencing normal coagulation as well as pathological thrombus formation. The present study was undertaken to identify the cellular site(s) of synthesis of this inhibitor and to delineate pathological conditions that influence its plasma level. Data are presented that suggest that the inhibitor is synthesized in liver and endothelial cells and is consumed during disseminated intravascular coagulation (DIC).

\section{Methods}

Materials. Human vein endothelial cells (HUVE) were harvested from human umbilical cords by the method of Jaffe et al. (6). Bovine pulmonary artery endothelial cell line (BPAE) described by Del Vecchio and Smith (7) and the HL-60 cell line established from the peripheral blood of a patient with acute promyelocytic leukemia (8) were obtained from the American Type Culture Collection, Rockville, MD. The U937 cell line established from the pleural effusion of a patient with histiocytic lymphoma (9) was originally provided by Dr. Hillel S. Koren, Duke University, Durham, NC. The HepG2 cell line derived from a human hepatoblastoma (10) was provided by Dr. Jung San Huang of St. Louis University, St. Louis, MO. Human brain tissue factor was prepared as described previously (11); the suspension was centrifuged as earlier (11) and the supernatant that clotted recalcified plasma in $24 \mathrm{~s}$ was used throughout. Chemicals for electrophoresis were purchased from Bio-Rad Laboratories, Richmond, CA. Tissue culture media and supplements were obtained from K. C. Biological, Inc., Lenexa, KS, and the hereditary clotting factor-deficient plasmas were obtained from George King Biomedical, Overland Park, KS. Endotoxin (Bacto lipopolysaccharide, E. coli 0127, B8) was obtained from Difco Laboratories Inc., Detroit, MI. Heparin and cycloheximide were received from Sigma Chemical Company, St. Louis, MO. Dansyl-glu-gly-arg-chloromethyl ketone (DEGR-CK) was obtained from Calbiochem-Behring Corp., La Jolla, $\mathrm{CA}$, and $\mathrm{Na}\left({ }^{3} \mathrm{H}\right)$ borohydride from Amersham Corp., Arlington Heights, IL. Bovine plasma was obtained from a local slaughterhouse. Other chemicals were of the best commercially available grade.

Proteins. Human Factor VII (12), Factor IX (13), and Factor X (13) were purified to homogeneity as described previously. Sialyl ${ }^{3} \mathrm{H}$-Factor IX was prepared by the general technique of Van Lenten and Ashwell (14). The procedure was slightly modified in that the reagent $\mathrm{NaIO}_{4}$ was used at a twofold molar concentration to the sialic acid content of Factor IX. Specific activity of the preparation was $2 \times 10^{8} \mathrm{cpm} / \mathrm{mg}$ and the radiolabeled protein retained $91 \%$ of the clotting activity of the nonlabeled control. Factor Xa was prepared as described (13); it was coupled to Sepharose 4B by a procedure as outlined for Russells viper venom (13). Factor VIIa was obtained as earlier except insoluble factor Xa (Sepharose$\mathrm{Xa}$ ) was used instead of the soluble factor $\mathrm{Xa}$ as the activator (15). The resin was removed by centrifugation and the supernatant was passed over a small Chelex-100 column. Factor VIla obtained in this manner had a specific activity of $35 \mathrm{U} / \mu \mathrm{g}$; it was kept at $4^{\circ} \mathrm{C}$ and used within $24 \mathrm{~h}$ of preparation. DEGR-Xa was prepared by incubating Factor Xa 
$(\sim 2 \mu \mathrm{M})$ with 30 -fold molar excess of DEGR-CK. The conditions employed including the removal of free label were exactly the same as outlined for Factor XIa (16). DEGR-Xa had $<1 \%$ of the clotting activity of unmodified Factor Xa. Anti-Factor $\mathrm{X}$ and anti-protein $\mathrm{C}$ antibody were prepared as previously described (17).

Gel electrophoresis. Sodium dodecyl sulfate (SDS) gel electrophoresis was performed according to the method of Laemmli, utilizing $12 \%$ acrylamide gels (18).

Cell culture. HUVE and BPAE cells were grown as previously described (19). HUVE cells obtained from three umbilical cords were routinely used for seeding one $T-25 \mathrm{~cm}^{2}$ flask. The cells grew to confluence within 4-5 d in M199 supplemented with 20\% heat-inactivated fetal calf serum (FCS), $90 \mu \mathrm{g} / \mathrm{ml}$ heparin, and $35 \mu \mathrm{g} / \mathrm{ml}$ endothelial cell growth supplement. Cells were determined to be of endothelial cell origin as described earlier by Wysolmerski and Lagunoff (19). Cells (2-4 d postconfluent) were washed five times with the culture medium (without heparin and FCS) and then cultured overnight (20-24 h) in serum- and heparin-free medium. Conditioned medium was collected, centrifuged to remove any debris, and frozen at $-20^{\circ} \mathrm{C}$ until used. BPAE cells were grown in Eagle's minimal essential medium supplemented with $2 \mathrm{mM}$ glutamine, $10 \% \mathrm{FCS}, 50 \mathrm{U} / \mathrm{ml}$ penicillin, and $50 \mu \mathrm{g} / \mathrm{ml}$ streptomycin. HepG2 cells were cultured in Dulbecco's modified Eagle's medium supplemented with $10 \%$ FCS and $1 \%$ nonessential amino acids. Serum-free conditioned media from BPAE cells ( $6 \mathrm{~d}$ postconfluent) and HepG2 cells ( $2 \mathrm{~d}$ postconfluent) were obtained in a similar manner as for HUVE cells. The HL-60 and U937 cells were maintained in RPMI-1640 medium supplemented with $10 \%$ FCS as previously outlined (20). To collect conditioned media, the cells were washed three times, resuspended to a density of $\sim 2 \times 10^{6} \mathrm{cells} / \mathrm{ml}$ in serum-free RPMI media, and cultured for $\sim 22 \mathrm{~h}$. All cells were maintained at $37^{\circ} \mathrm{C}$ in a humidified atmosphere of $5 \% \mathrm{CO}_{2}$ in air. In experiments where cycloheximide was used, its final concentration was $1 \mu \mathrm{g} / \mathrm{ml}$ in the medium.

Induction of DIC in rabbits. Our experimental protocol for inducing DIC in rabbits was the same as outlined in detail by Rapaport and associates $(21,22)$ except that we used dexamethasone sodium phosphate (Merck Sharp \& Dohme, West Point, PA) instead of cortisone acetate. Six New Zealand rabbits $(\sim 2.5 \mathrm{~kg}$ ) were divided into two groups. All three rabbits in Group A received $1 \mathrm{ml}$ of isotonic saline intramuscularly daily for $4 \mathrm{~d}$. The three rabbits in Group B received $4 \mathrm{mg}$ of dexamethasone (instead of saline) intramuscularly for $4 \mathrm{~d}$. On day 5 and $24 \mathrm{hr}$ later (day 6), one rabbit from each group received intravenous injections of saline, and the remaining two from each group received intravenous injections of endotoxin $(75 \mu \mathrm{g} / \mathrm{kg})$. Blood samples from the ear veins were drawn from all animals $10 \mathrm{~min}$ before the first injection of saline or dexamethasone to establish base line levels of fibrinogen, platelets, Factor V, and Factor VIII. Blood samples were again collected (starting on day 5) $\sim 30$ min before and 4 and $24 \mathrm{~h}$ after the injections of saline or endotoxin. Additional samples were obtained from those animals that survived after the final injection of saline or endotoxin.

Plasma specimens. Patient specimens were obtained at the St. Louis University Medical Center. Use of volunteer blood donors was approved by the Human Subjects Committee of St. Louis University. All samples obtained were ensured to be free of heparin. Patients with chronic hepatocellular disease had one of the following: history of longstanding alcohol abuse, chronic active hepatitis, hemochromatosis, or postnecrotic cirrhosis. The diagnostic criteria for these patients were $(a)$ history of predisposing cause, $(b)$ stigmata of chronic hepatocellular disease on physical examination, (c) abnormal laboratory tests such as markedly decreased serum albumin levels, elevated serum bilirubin levels, prolonged prothrombin time, and decreased protein $C$ antigen $(<47 \%$ of normal as measured by an electroimmunoassay), and $(d)$ histopathological evidence of chronic liver disease by biopsy or autopsy in five of the patients. Patients with DIC had one of the following: (a) gram-negative sepsis (seven patients), (b) gram-positive sepsis (two patients), or (c) severe trauma (one patient). The laboratory diagnostic criteria for these patients were prolonged prothrombin time, prolonged activated partial thromboplastin time, decreased platelet count, and elevated fibrin/fibrinogen degradation products $(>10 \mu \mathrm{g} / \mathrm{ml}$, as measured by Thrombo-Wellco test). Patients on long-term warfarin therapy due to atrial fibrillation, prosthetic heart valves, arterial or venous thrombosis, or pulmonary thromboembolism who were on stable maintenance dose were selected for the inhibitor analysis. The protein $C$ antigen in these patients was $<53 \%$ of normal. Lupus anticoagulant patients were selected based upon the criteria described elsewhere (23). Two of the patients had a clinical history of thrombotic disease. Plasma samples of patients with deep venous thrombosis as diagnosed by either venography or impedance plethysmography were collected before receiving any treatment.

$V I I a / T F$ inhibitor assay. The assay was conducted in two steps and all reagents were diluted in $0.05 \mathrm{M}$ Tris, $0.15 \mathrm{M} \mathrm{NaCl}, \mathrm{pH} 7.5$ (Tris/ $\mathrm{NaCl}$ ) containing $1 \mathrm{mg} / \mathrm{ml}$ of bovine serum albumin (Tris/ $\mathrm{NaCl} / \mathrm{Alb}$ ). In the first step, $50 \mu \mathrm{l}$ of Factor $X(70 \mu \mathrm{g} / \mathrm{ml})$ was incubated with 100 $\mu \mathrm{l}$ of Factor VII $(25 \mu \mathrm{g} / \mathrm{ml}), 50 \mu \mathrm{l}$ of diluted tissue factor, and $31 \mu \mathrm{l}$ of $75 \mathrm{mM} \mathrm{CaCl}_{2}$ at $37^{\circ} \mathrm{C}$ for $10 \mathrm{~min}$. During this incubation time, Factor VII was completely converted to Factor VIIa, and $>90 \%$ of Factor X was converted to Factor $\mathrm{Xa}$. The reaction was quenched by the addition of $36 \mu \mathrm{l}$ of $75 \mathrm{mM} \mathrm{Na} \mathrm{N}_{2}$ EDTA. In the second step, 15- $\mu$ l aliquots of the above incubation mixture were added to various tubes containing $50 \mu \mathrm{l}$ of ${ }^{3} \mathrm{H}$-Factor IX $(5 \mu \mathrm{g} / \mathrm{ml})$ and $20 \mu \mathrm{l}$ of different dilutions of plasma or test material. The reaction was initiated by the addition of $15 \mu \mathrm{l}$ of 70 $\mathrm{mM} \mathrm{CaCl} 2$. The tubes were incubated for the desired length of time at $37^{\circ} \mathrm{C}$ at which point $100 \mu \mathrm{l}$ of cold stopping buffer (Tris/ $\mathrm{NaCl}$ containing $50 \mathrm{mM}$ benzamidine, $50 \mathrm{mM}$ EDTA, and $5 \mathrm{mg} / \mathrm{ml}$ bovine serum albumin) was added. Trichloroacetic acid (TCA) soluble counts in these tubes were then determined as described earlier $(24,25)$. Background counts ( $\sim 2 \%$ of total) were subtracted from the sample counts to determine the percent TCA-soluble counts. Complete activation of Factor IX yielded 35\% TCA-soluble counts. Human pooled plasma from 20 donors was arbitrarily assigned to contain $100 \mathrm{U} / \mathrm{ml}$ of VIIa/TF inhibitor activity. Thus, a test sample containing $10 \mathrm{U} / \mathrm{ml}$ of inhibitor activity is equal to $10 \%$ of plasma levels of inhibitor.

\section{Results}

Quantitative assay for VIIa/TF inhibitor activity. The present assay was developed based upon the rationale that TF should be the only limiting reagent, and that the small amounts of Factor IX contributed by plasma in the assay should not influence the fraction of ${ }^{3} \mathrm{H}$-Factor IX activated at early time points. Both conditions were met when a diluted TF preparation and a high Factor VII concentration were employed, which in the absence of the inhibitor yielded $\sim 10 \%$ TCA-soluble counts (after 30 min incubation; Fig. 1 , inset [๑]) at a ${ }^{3} \mathrm{H}$-Factor IX concentration of $44 \mathrm{nM}\left(\sim 5\right.$ times below the $K_{\mathrm{m}}$ value, reference 2$)$. Thus, when the concentration of tissue factor was doubled, the initial rate of ${ }^{3} \mathrm{H}$-Factor IX activation was correspondingly increased (Fig. 1, inset $[X]$ ). Similarly, when nonlabeled Factor IX at a concentration of $17 \mathrm{nM}$ (the amount of Factor IX contributed by $10 \%$ plasma in the assay is $7 \mathrm{nM}$ ) was also present in the assay, it had no detectable influence on the percent activation of ${ }^{3} \mathrm{H}$-Factor IX (Fig. 1, inset [O]). Also, the inhibitory activity was not increased when Factor $X$ concentration was increased by a factor of $3 / 2$. Furthermore, inhibition was not observed when Factor Xa formed in the first step and Factor X present in normal plasma were neutralized by anti-Factor $X$ antibodies before conducting the second step of the assay. Inhibition was also not observed when preformed Factor VIIa and active site blocked Factor Xa (DEGR-Xa) were used in the first step and congenitally Factor $\mathrm{X}$-deficient plasma was used in the second step of the assay. From these observations, we conclude that the inhibitory activity observed in our assay is due to a VIIa/TF inhibitor that specifically requires Factor $\mathrm{Xa}$ for it to function. Because inhibition was more pronounced when the incubation was carried out for $30 \mathrm{~min}$ (Fig. 1, inset), we selected this in- 


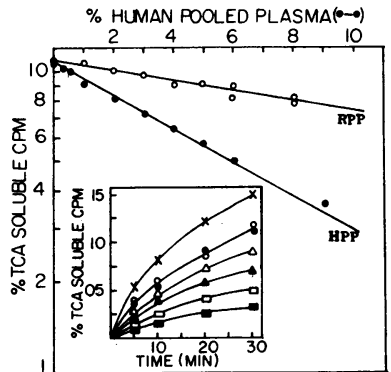

Figure 1. VIIa/TF inhibitor assay standard curve. The incubation mixtures contained ${ }^{3} \mathrm{H}$-Factor IX $(2.5 \mu \mathrm{g} / \mathrm{ml}$ or $44 \mathrm{nM})$, Factor VIIa $(1.4 \mu \mathrm{g} / \mathrm{ml}$ or $28 \mathrm{nM})$, Factor Xa $(2 \mu \mathrm{g} / \mathrm{ml}$ or $34 \mathrm{nM})$, diluted TF (2.8\% vol/vol), $\mathrm{CaCl}_{2}(10 \mathrm{mM})$, and various dilutions of HPP (๑) or rabbit pooled plasma (RPP) (0). Each reaction volume was $100 \mu \mathrm{l}$ and the diluent was Tris $/ \mathrm{NaCl} /$

Alb. The reactions were terminated at $30 \mathrm{~min}$ and percent TCA-soluble cpm were determined as described $(24,25)$. The logarithm of percent TCA-soluble CPM is plotted against the percent HPP or the percent RPP. Human plasma was pooled from 20 donors and rabbit plasma was pooled from four animals. Inset, kinetics of activation of ${ }^{3} \mathrm{H}$-Factor IX under various conditions. Percent TCA-soluble cpm are plotted against time. Each reaction mixture contained all of the reagents listed above with the follow-

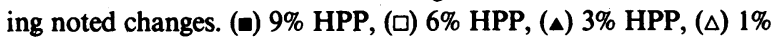
HPP, (๑) 0\% HPP (buffer control), (O) 0\% HPP and $17 \mathrm{nM}$ nonlabeled Factor IX in addition to $44 \mathrm{nM}^{3} \mathrm{H}$-Factor IX, and $(X) 0 \%$ HPP and $5.6 \%$ (instead of $2.8 \%$ ) tissue factor.

cubation time for routine analysis. We also plotted the data in several ways and found that the best fit $(r=0.98)$ was obtained when the logarithm of percent TCA-soluble counts was plotted against the inhibitor units (Fig. 1). In this assay, the within-run coefficient of variation was $5-10 \%$ and the between-run coefficient of variation was $<10 \%$. Sensitivity of the assay was about $0.5 \%$ of plasma level.

VIIa/TF inhibitor activity in various disease states. VIIa/ TF inhibitor was assayed in plasma from 25 healthy volunteers using human pooled plasma (HPP) as a reference. The values ranged from 72 to $142 \mathrm{U} / \mathrm{ml}$ with a mean of $101 \mathrm{U} / \mathrm{ml}$ (Fig. 2). When plasma inhibitor levels of 10 patients with DIC were assayed, the inhibitor was found to be significantly reduced (mean $57 \pm 30 \mathrm{U} / \mathrm{ml} ; P<0.001$ ). However, when plasma inhibitor levels

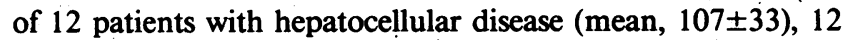
patients on chronic warfarin therapy (mean, 105 \pm 35 ), 11 patients with the lupus anticoagulant (mean, 101 \pm 39 ), and 11 patients with deep vein thrombosis (mean, 107 \pm 30 ) were measured, the inhibitor activity was found to be within normal limits (Fig. 2).

VIIa/TF inhibitor activity in plasma from rabbits after induction of DIC. Fibrinogen, platelets, Factor V, and Factor VIII levels remained within normal limits $( \pm 10 \%)$ in the rabbit treated with saline only (rabbit 1 of Fig. $3 A$ ) and in the rabbit treated with dexamethasone followed by saline (rabbit 1 of Fig. $3 B$ ).

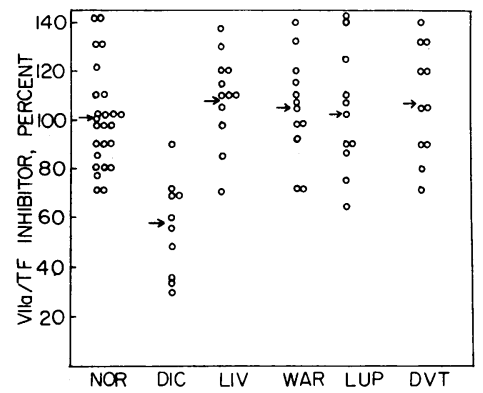

Figure 2. Distribution of VIIa/TF inhibitor activity in plasma from 25 normal subjects $(N O R), 10$ patients with DIC (DIC), 12 patients with hepatocellular disease (LIV), 12 patients on chronic warfarin therapy $(W A R), 11$ patients with the lupus anticoagulant (LUP), and 11 patients with deep venous thrombosis $(D V T)$. Arrow represents mean of data points for each patient group.

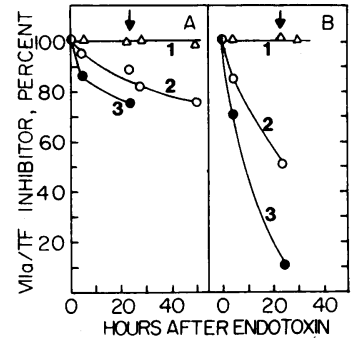

Figure 3. VIIa/TF inhibitor activity in plasma of rabbits after endotoxin treatment. The standard curve labeled $R P P$ in Fig. 1 was used to measure the inhibitory activity. Rabbits in Group $A$ were given saline daily for $4 \mathrm{~d}$ and rabbits in Group B were given dexamethasone daily for $4 \mathrm{~d}$. On day 5 (zero hour on abscissa) and $24 \mathrm{~h}$ later (indicated by arrow), one rabbit in each group (labeled $I$ in $A$ and $B$ ) received saline, and two rabbits in each group (labeled 2 and 3 in both $A$ and $B$ ) received endotoxin. For details, see Methods.

Fibrinogen, platelets, Factor V, and Factor VIII levels fell to between 60 and $70 \%$ of the basal levels in the two rabbits (labeled 2 and 3 in Fig. $3 A$ ) of Group A $4 \mathrm{~h}$ after receiving endotoxin and remained depressed to the same degree after $24 \mathrm{~h}$ except for fibrinogen, which rose in both cases to between 130 and 140\%. One rabbit (labeled 3 in Fig. $3 A$ ) died within $2 \mathrm{~h}$ after receiving the second injection of endotoxin. The other rabbit (labeled 2 in Fig. $3 \mathrm{~A}$ ) did not show further depression of any of the above clotting factors. The two rabbits that received endotoxin after dexamethasone treatment showed excessive reduction in the clotting factors as compared with those that received saline instead of dexamethasone. After $4 \mathrm{~h}$ of endotoxin injection, the levels of various factors in the two rabbits (labeled 2 and 3 in Fig. $3 B$; first number is for rabbit 2 and the second number is for rabbit 3) treated with dexamethasone were: fibrinogen, 43 and 34\%; platelets, 41 and 47\%; Factor V, 73 and 68\%; and Factor VIII, 52 and 28\%. After $24 \mathrm{~h}$ of endotoxin injection the levels were: fibrinogen, 129 and $118 \%$; platelets, 37 and 43\%; Factor V, 45 and 32\%; and Factor VIII, 23 and $28 \%$. Both rabbits died within $2 \mathrm{~h}$ of receiving the second injection of endotoxin. The above measurements establish that we did induce DIC in all four rabbits that received endotoxin. Moreover, as previously reported $(21,22)$, steroid (dexamethasone in our study) treatment enhanced intravascular clotting.

$\mathrm{VIIa} / \mathrm{TF}$ inhibitor levels fell in all four rabbits that received endotoxin (Fig. 3). The level of the inhibitor in the two rabbits that did not receive dexamethasone (labeled 2 and 3 in Fig. 3 $A$ ) fell by $\sim 25 \%$ after $24 \mathrm{~h}$ from the first endotoxin injection. In rabbit 2 , the level of the inhibitor began rising $48 \mathrm{~h}$ after the second endotoxin injection and was normal after $72 \mathrm{~h}$. The level of the inhibitor in the two rabbits that received dexamethasone (labeled 2 and 3 in Fig. 3 B) fell by $\sim 70 \%$ (average of 50 and $90 \%)$ after $24 \mathrm{~h}$ from the first endotoxin injection. Thus, although we recognize that we have obtained data with a limited number of animals, we believe it is valid to conclude that the inhibitor is reduced in DIC.

VIIa/TF inhibitor activity in conditioned media of various cell cultures. Studies in a previous section established that the inhibitor is not reduced in patients with severe hepatocellular disease. To account for this observation and identify site(s) of synthesis of this inhibitor, we assayed activity of the inhibitor in supernatants of several cell cultures. These data are presented in Table I. HepG2, HUVE, and BPAE cells all synthesized and secreted this inhibitor. Furthermore, cycloheximide inhibited the synthesis. U937 cell supernatants contained small amounts of this inhibitor, whereas HL-60 cell supernatants contained no detectable activity. In each cell type, inhibition was not observed if Factor Xa formed in the first step was neutralized by Anti- 
Table I. VIIa/TF Inhibitor Activity in

Supernatants of Various Cell Cultures

\begin{tabular}{|c|c|c|c|}
\hline Cell type & Origin & Treatment & $\begin{array}{l}\text { Activity in } \\
\text { conditioned medium } \\
\text { adjusted to } \\
10^{6} \mathrm{cell} / \mathrm{s} / \mathrm{ml}\end{array}$ \\
\hline \multirow[t]{2}{*}{ HepG2 } & $\begin{array}{l}\text { Human } \\
\text { hepatoblastoma }\end{array}$ & None & $4.9 \pm 0.5$ \\
\hline & & Cycloheximide & $\sim 0.3$ \\
\hline \multirow[t]{2}{*}{ HUVE } & $\begin{array}{l}\text { Human umbilical } \\
\text { vein }\end{array}$ & None & $3.9 \pm 0.3$ \\
\hline & & Cycloheximide & $\sim 0.3$ \\
\hline BPAE & $\begin{array}{l}\text { Bovine } \\
\text { pulmonary } \\
\text { artery }\end{array}$ & None & $3.3 \pm 0.3$ \\
\hline U937 & $\begin{array}{l}\text { Human } \\
\text { histiocytic } \\
\text { lymphoma }\end{array}$ & None & $\sim 0.3$ \\
\hline HL-60 & $\begin{array}{l}\text { Human } \\
\text { promyelocytic } \\
\text { leukemia }\end{array}$ & None & Undetectable \\
\hline
\end{tabular}

HepG2 $\left(\sim 5 \times 10^{6}\right)$, HUVE $\left(\sim 3 \times 10^{6}\right)$, and BPAE $\left(\sim 3 \times 10^{6}\right)$ cells were grown to confluent monolayers in $T-25 \mathrm{~cm}^{2}$ culture flasks containing $5 \mathrm{ml}$ of appropriate medium supplemented with $10 \%$ inactivated FCS. Conditioned media were obtained by incubating cultures for 20-24 $\mathrm{h}$ in the absence of FCS. When cycloheximide was used, its concentration was $1 \mu \mathrm{g} / \mathrm{ml}$. U937 and HL-60 cells were grown in T-75 $\mathrm{cm}^{2}$ flasks. Cells were spun, washed, and resuspended in media without FCS and cultured for $\sim 22 \mathrm{~h}$. After culturing, the number of cells were $\sim 2 \times 10^{6} / \mathrm{ml}$ for both U937 and HL-60 cell lines. Cells were spun and supernatants were assayed before and after 20 -fold concentration. Activity in conditioned medium is the mean of two experiments performed in duplicate. Complete growth media when tested for the inhibitor were found to be negative. For HepG2, HUVE, and U937 cells, activity is presented as percentage of HPP and for BPAE it is presented as percentage of bovine plasma from a single animal (a standard curve using bovine plasma was constructed for this purpose).

Factor $\mathrm{X}$ antibodies. Inhibition was also not observed if the test samples were incubated at $100^{\circ} \mathrm{C}$ for $5 \mathrm{~min}$ before assay.

In further experiments, we concentrated HPP and the conditioned media from HepG2 and HUVE cells. These samples were then run on SDS gels. The proteins were eluted and assayed for the inhibitor activity. In each case, two peaks of activity were identified-one corresponding to $45,000 \pm 2,000$ and the second corresponding to $33,000 \pm 2,000 \mathrm{~mol} \mathrm{wt}$ (Fig. 4).

\section{Discussion}

In this communication, we have developed a radioassay for VIIa/ TF inhibitor that specifically requires Factor $\mathrm{Xa}$ to function. Both the sensitivity and precision of the assay are appropriate for measurements of the inhibitor levels in clinical specimens. Using this assay, we show that the inhibitor levels are significantly depressed in patients with DIC. Of the 10 patients investigated, one patient with trauma had a level of $35 \%$, two patients with gram-positive sepsis had levels of $\sim 70 \%$, and seven patients with gram-negative sepsis had levels of $27-87 \%$ (Fig. 2). Our animal studies using a rabbit model system support our measurements of the inhibitor level in DIC patients. Furthermore, in earlier studies $(21,22)$, enough evidence has been presented

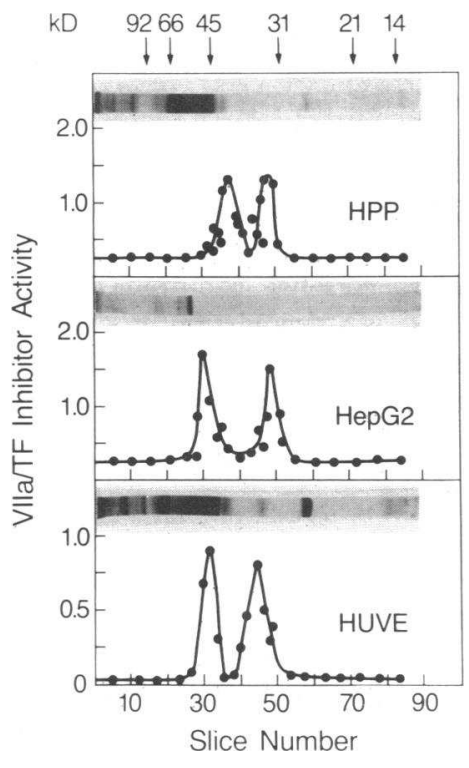

Figure 4. Elution of VIIa/ TF inhibitor activity from SDS gels. Proteins present in the $40-70 \%$ ammonium sulfate precipitate of HPP, HepG2, and HUVE were dialyzed extensively against Tris/ $\mathrm{NaCl}$ buffer. $\sim 150 \mu \mathrm{l}$ of sample containing $\sim 12$ $\mathrm{U} / \mathrm{ml}$ of $\mathrm{VIIa} / \mathrm{TF}$ inhibitor activity was applied to each gel in the absence of a reducing agent. Gels were sliced into 1-mm segments and each slice was soaked in $0.1 \mathrm{ml}$ of $\mathrm{Tris} / \mathrm{NaCl} / \mathrm{Alb}$ buffer in plastic tubes overnight. Each sample was then dialyzed extensively against $\mathrm{Tris} / \mathrm{NaCl}$ buffer to remove SDS. The VIIa/TF inhibitor activity was determined as described in

Methods except $60 \mu \mathrm{l}$ (instead of $20 \mu \mathrm{l}$ ) of sample and $10 \mu \mathrm{l}$ (instead of $50 \mu \mathrm{l}$ ) of fivefold concentrated ${ }^{3} \mathrm{H}$-Factor IX was used. This enhanced the sensitivity of the assay threefold. Duplicate stained gels (20 $\mu$ l sample) in each case are also depicted. Molecular weight markers obtained from Bio-Rad Laboratories are phosphorylase B $(92,500)$, bovine serum albumin $(66,000)$, Ovalbumin $(45,000)$, carbonic anhydrase $(31,000)$, soybean trypsin inhibitor $(21,500)$, and lysozyme $(14,000)$.

to suggest that the endotoxin-induced clotting is initiated by the tissue factor pathway. Thus, in eight of our patients (seven with gram-negative sepsis and one with trauma), the clotting is most likely initiated by tissue factor. If so, our findings support a hypothesis that reduced levels of the inhibitor in patients with DIC represent depletion through consumption.

The lupus anticoagulant is associated with an increased incidence of thrombosis (23). Decreased levels (antibody-mediated or otherwise) of VIIa/TF inhibitor could contribute to the pathogenesis of thrombosis in these patients. For this reason, we measured the levels of this inhibitor in 11 patients with the lupus anticoagulant. None of the patients appeared to have abnormal levels of this inhibitor. Thus, the cause of thrombosis in the majority of patients with the lupus anticoagulant does not appear to be due to decreased levels of this inhibitor. We also measured the levels of this inhibitor in patients with deep vein thrombosis in a search for evidence that a deficiency of this inhibitor could predispose such individuals to thrombosis. None of the patients examined thus far showed reduced levels of this inhibitor. The inhibitor levels were also not reduced in patients undergoing chronic warfarin therapy, suggesting that the inhibitor is not a vitamin $\mathrm{K}$-dependent protein.

We also measured the VIIa/TF inhibitor activity in 12 patients with advanced hepatocellular disease. The inhibitor levels were found to be normal in these patients. This was an unexpected finding, because in a preliminary report, Broze and Miletich (26) demonstrated that a liver cell ine (HepG2) produces this inhibitor. In this report, we have found that in addition to the HepG2 cells, endothelial cells also produce this inhibitor in significant amounts. In fact, our patient data would indicate that endothelial cells may be the major source of this inhibitor in vivo. 
To examine if the inhibitor found in human plasma is similar to the inhibitor produced by HepG2 and HUVE cells in culture, we performed SDS gel electrophoresis on protein samples from each of these three sources. In each case, the inhibitory activity was found at $45,000 \pm 2,000 \mathrm{D}$ and at $33,000 \pm 2,000 \mathrm{D}$. WarnCramer and associates have also found that the inhibitory activity in human plasma is present at mol wt of $\sim 43,000$ and $\sim 34,000$ (27 and Dr. B. Warn-Cramer, personal communication). Whether the 34,000 mol wt form is a degradation product of the $43,000 \mathrm{~mol}$ wt form is not known. However, both forms require Factor Xa to function (Dr. B. Warn-Cramer, personal communication).

\section{Acknowledgments}

We are indebted to Dr. J. Heinrich Joist (Director, Clinical Hemostasis Laboratory) for his generous support and constant encouragement. We thank Dr. Coy Fitch (Chairman, Department of Medicine) for allowing Dr. M. S. Bajaj to carry out these studies during her residency (Internal Medicine) training. We thank Drs. Joachim Reimers and Steve Janney for their interest and helpful discussions.

This work was supported by National Institutes of Health Research Grant HL-36365 and American Heart Association Grant-In-Aid 86-1182. Dr. S. P. Bajaj is supported in part by an American Heart Association Established Investigator Award (No. 83-176). Dr. Wysolmerski is supported by a training grant (HL-07050).

\section{References}

1. Østerud, B., and S. I. Rapaport. 1977. Activation of factor IX by the reaction product of tissue factor and factor VII. Proc. Natl. Acad. Sci. USA. 74:5260-5264.

2. Warn-Cramer, B. J., and S. P. Bajaj. 1986. Intrinsic versus extrinsic coagulation. Biochem. J. 239:757-762.

3. Lanchantin, G. F., and A. G. Ware. 1953. Identification of a thromboplastin inhibitor in serum and in plasma. J. Clin. Invest. 32: 381-389.

4. Carson, S. D. 1981. Plasma high density lipoproteins inhibit the activation of coagulation factor $\mathrm{X}$ by factor VIIa and tissue factor. FEBS (Fed. Eur. Biochem. Soc.) Lett. 132:37-40.

5. Sanders, N. L., S. P. Bajaj, A. Zivelin, and S. I. Rapaport. 1985. Inhibition of tissue factor/factor VIIa activity in plasma requires factor $\mathrm{X}$ and an additional plasma component. Blood. 66:204-212.

6. Jaffe, E. A., R. L. Nachman, G. G. Becher, and C. R. Minick. 1973. Culture of endothelial cells derived from umbilical veins. J. Clin. Invest. 52:2745-2756.

7. Del Vecchio, P. J., and J. R. Smith. 1981. Expression of angiotensinconverting enzyme activity in cultured pulmonary artery endothelial cell. J. Cell. Physiol. 108:337-345.

8. Collins, S. J., R. C. Gallo, and R. E. Gallagher. 1977. Continuous growth and differentiation of human myeloid leukemic cells in suspension culture. Nature (Lond.). 270:347-349.

9. Sundstrom, C., and K. Nilsson. 1976. Establishment and characterization of a human histiocytic lymphoma cell line (U937). Int. J. Cancer. 17:565-577.

10. Aden, D. P., A. Fogel, S. Plotkin, I. Damjanov, and B. B. Knowles. 1979. Control synthesis of $\mathrm{HBsAg}$ in a differentiated human liver carcinoma-derived cell line. Nature (Lond.). 282:615-616.

11. Bajaj, S. P., S. I. Rapaport, and W. A. Russell. 1983. Redetermination of the rate-limiting step in the activation of factor IX by factor $\mathrm{XIa}$ and factor VIIa/tissue factor. Biochemistry. 22:4047-4053.

12. Rao, L. V. M., and S. P. Bajaj. 1984. Purification of human factor VII utilizing O-(diethylaminoethyl)-Sephadex and SulfopropylSephadex chromatography. Anal. Biochem, 136:357-361.

13. Bajaj, S. P., S. I. Rapaport, and C. Prodanos. 1981. A simplified procedure for purification of human prothrombin, factor IX and factor X. Prep. Biochem. 11:397-412.

14. Van Lenten, L., and G. Ashwell. 1971. Studies on the chemical and enzymatic modifications of glycoproteins. J. Biol. Chem. 246:18891894.

15. Bajaj, S. P., S. I. Rapaport, and S. F. Brown. 1981. Isolation and characterization of human factor VII. J. Biol. Chem. 256:253-259.

16. Warn-Cramer, B. J., and S. P. Bajaj. 1985. Stoichiometry of binding of high molecular weight kininogen to factor XI/XIa. Biochem. Biophys. Res. Commun. 133:417-422.

17. Bajaj, S. P., S. I. Rapaport, S. L. Maki, and S. F. Brown. 1983. A procedure for isolation of human protein $\mathrm{C}$ and protein $\mathrm{S}$ as byproducts of the purification of factors VII, IX, X and prothrombin. Prep. Biochem. 13:191-214.

18. Laemmli, V. K. 1970. Cleavage of structural proteins during the assembly of the head of bacteriophage T4. Nature (Lond.). 227:680-685.

19. Wysolmerski, R., and D. Lagunoff. 1985. The effect of ethchlorvynol on cultured endothelial cells. Am. J. Pathol. 119:505-512.

20. Hudig, D., and S. P. Bajaj. 1982. Tissue factor-like activity of the human monocytic tumor cell line U937. Thromb. Res. 27:321-332.

21. Lerner, R. G., S. I. Rapaport, and J. M. Spitzer. 1968. Endotoxin induced intravascular clotting. Thromb. Diath. Haemorrh. 20:430-443.

22. Shen, S. M.-C., and S. I. Rapaport. 1974. Increased fibrinogen consumption following endotoxin injection in cortisone-treated rabbits. Proc. Soc. Exp. Biol. Med. 145:851-854.

23. Meuh, J. R., K. D. Herbst, and S. I. Rapaport. 1980. Thrombosis in patients with the lupus anticoagulant. Ann. Intern. Med. 92:156-159.

24. Zur, M., and Y. Nemerson. 1980. Kinetics of factor IX activation via the extrinsic pathway. J. Biol. Chem. 255:5703-5707.

25. Bajaj, S. P. 1982. Cooperative $\mathrm{Ca}^{2+}$ binding to human factor IX. J. Biol. Chem. 257:4127-4132.

26. Broze, G. J., and J. P. Miletich. 1986. Characterization of the inhibition of tissue factor in serum. Circulation. 74:II-409. (Abstr.)

27. Warn-Cramer, B., L. V. M. Rao, S. Maki, A. Zivelin, and S. I. Rapaport. 1986. Partial purification of a factor X-dependent plasma inhibitor of the factor VIIa/tissue factor complex. Circulation. 74:II-408. (Abstr.) 